\title{
New records of Praethecacineta halacari (Schulz) (Suctorea: Ciliophora) from Taiwan, Tanzania and Canada
}

\author{
IGOR DOVGAL ${ }^{1}$, TAPAS CHATTERJEE ${ }^{2}$, D.V. SUBBA RAO ${ }^{3,4}$, BENNY K.K. CHAN $^{5}$ AND MARLEEN DE TROCH $^{6}$ \\ ${ }^{1}$ Schmalhausen Institute of Zoology, B. Khmelnitsky str, 15, 01601, Kiev, Ukraine, ${ }^{2}$ Indian School of Learning, ISM Annexe, \\ PO-ISM, Dhanbad 826004, Jharkhand, India, ${ }^{3}$ Marine Environmental Sciences Division, Bedford Institute of Oceanography, PO \\ Box 1006, Dartmouth, Nova Scotia B2Y 4A2, Canada, ${ }^{4}$ Present address: 12 The Horseshoe, Manor Park, Dartmouth, Nova Scotia \\ $\mathrm{B}_{2} \mathrm{Y}_{4} \mathrm{E}_{5}$, Canada, ${ }^{5}$ Research Centre for Biodiversity, Academia Sinica, Taipei 115, Taiwan, ${ }^{6}$ Marine Biology Section, Department of \\ Zoology, Ghent University, Krijgslaan 281-S8, B-90oo Ghent, Belgium
}

\begin{abstract}
The present study reports on a range extension of the suctorian species Praethecacineta halacari to the region of He-Ping-Dao, north-east of Taiwan (West Pacific Ocean), Matemwe, the east coast of Unguja, Zanzibar, Tanzania (West Indian Ocean) and Nova Scotia, Canada (West Atlantic Ocean). Praethecacineta halacari is reported here for the first time from Taiwan, Tanzania and Canada. Earlier records include the Caspian Sea, Western Australia, Brazil, India, and various coastal sites in Europe.
\end{abstract}

Keywords: epibionts, suctorians, Praethecacineta halacari, range extension, Taiwan, Zanzibar, Canada

Submitted 4 May 2009; accepted 1 June 2009

\section{INTRDDUCTION}

Several species of suctorian ciliates are common epibionts of benthic marine and interstitial invertebrates (Precht, 1935; Jankowski, 1981, 2007; Dovgal, 1996, 2002; Dovgal et al., 2008a, b; Ingole et al., 2009). A number of suctorian ciliates have been observed as epibionts on various halacarid mites (Dovgal et al., 2008a). In this paper, we report Praethecacineta halacari (Schulz, 1933) as an epibiont on halacarid mites from Taiwan, Tanzania and Canada. This ciliate species is reported here for the first time from these coastal waters.

\section{MATERIALS AND METHDDS}

Halacarid mites were collected from He-Ping-Dao, north-east of Taiwan (West Pacific Ocean), Matemwe, the east coast of Unguja, Zanzibar, Tanzania (West Indian Ocean) and Nova Scotia, Canada (West Atlantic Ocean) (Figure 1). Standardized measurements were made using the computer program ScopePhoto 2.0 for processing digital images. All specimens are deposited in the collections of the Department of Fauna and Systematics of invertebrate animals of Schmalhausen Institute of Zoology, National Academy of Sciences, Ukraine.

RESULTS AND DISCUSSIDN

SYSTEMATICS

Class SUCTOREA Claparède \& Lachmann, 1859

Corresponding author:

I. Dovgal

Email: dovgal@izan.kiev.ua
Subclass EXOGENIA Collin, 1912

Order METACINETIDA Jankowski, 1978

Family PRAETHECACINETIDAE Dovgal, 1996

Praethecacineta halacari (Schulz, 1933) (Figures 2-4)

\section{MATERIAL EXAMINED}

Taiwan: 2 individuals were attached to Copidognathus sp. from He-Ping-Dao, north-east of Taiwan, $25^{\circ} 09^{\prime} 45^{\prime \prime} \mathrm{N} 121^{\circ} 45^{\prime} 46^{\prime \prime} \mathrm{E}$, West Pacific Ocean, among intertidal coralline algae in exposed rocky shores, 6 March 2007, Col. B.K.K. Chan.

Tanzania: 2 individuals were attached to Copidognathus ungujaensis Chatterjee, De Troch \& Chang from Matemwe, the east coast of Unguja, $05^{\circ} 52^{\prime} \mathrm{S} 39^{\circ} 21^{\prime} \mathrm{E}$, Zanzibar, Tanzania (West Indian Ocean) among coral rubble of Fungia, 17 August 2004, Col. M. Raes and H. Gheerardyn.

Canada: 8 individuals were attached to one halacarid mite from Nova Scotia, $44^{\circ} 38^{\prime} 15^{\prime \prime} \mathrm{N} 63^{\circ} 55^{\prime} 13^{\prime \prime} \mathrm{W}$, St Margaret's Bay, Canada (north-western Atlantic) in intertidal algae of the genus Enteromorpha on a rocky coast, September 2007, Col. DV Subba Rao.

\section{DIAGNOSIS}

Marine suctorians with stylotheca. Cell body weakly laterally flattened, entirely filling the lorica and attached to its posterior margin. Apical part of the body narrowed. Tentacles placed at upper cell surface. Macronucleus spherical posteriorly located; single contractile vacuole. Stylotheca smooth, without ribbing. Reproduction by semi-circumvaginative exogemmic budding with formation of laterally placed ciliate swarmers.

Body dimensions: body dimensions of $P$. halacari collected from Taiwan, Tanzania, Canada and India are given in Table 1. 


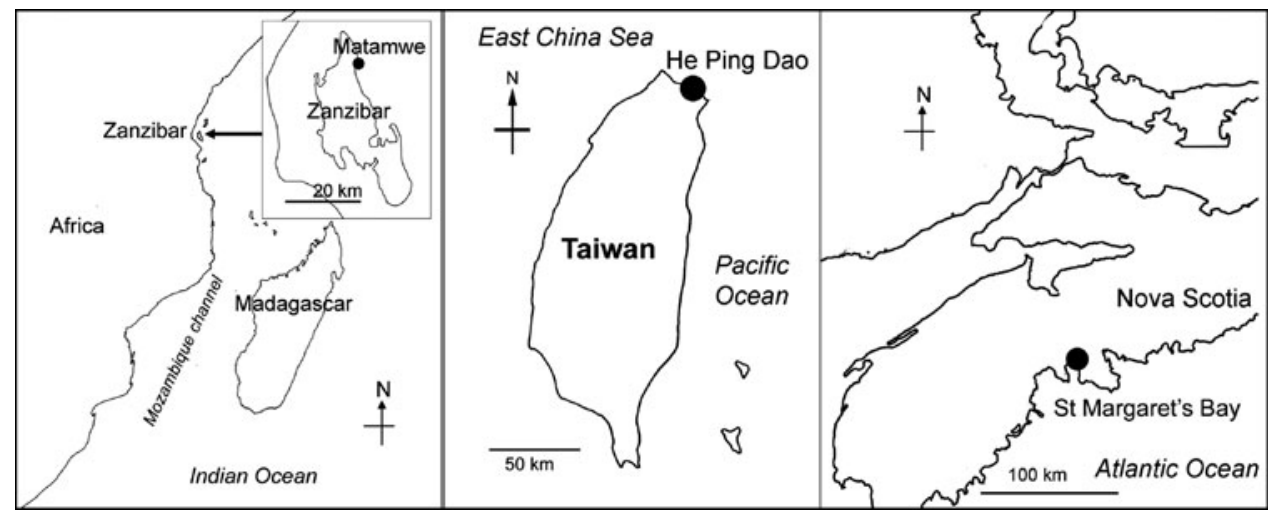

Fig. 1. Map showing the collection sites of Praethecacineta halacari reported in the present study.

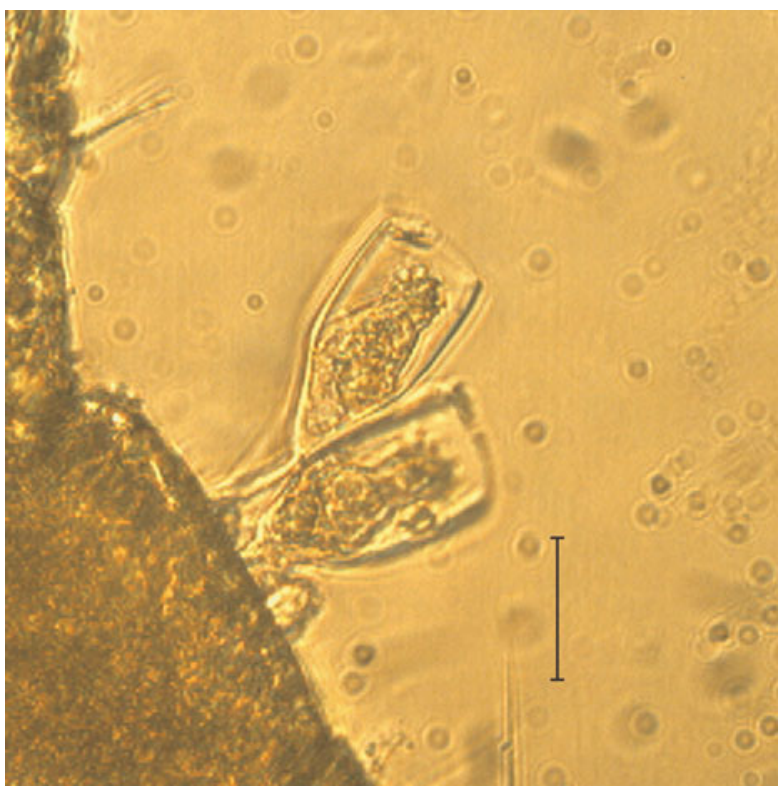

Fig. 2. Praethecacineta halacari attached to Copidognathus sp. from Taiwan. Scale bar $20 \mu \mathrm{m}$.

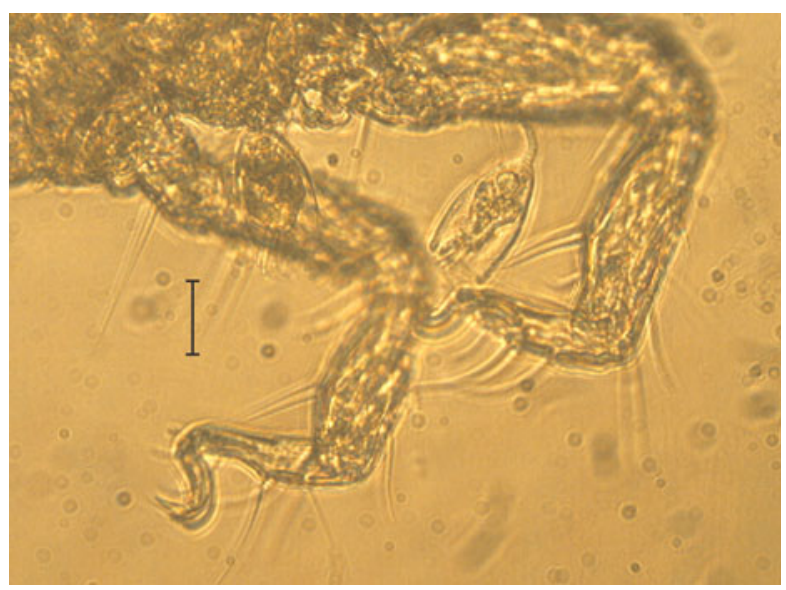

Fig. 3. Praethecacineta halacari attached to Copidognathus ungujaensis Chatterjee, De Troch \& Chang from Zanzibar, Tanzania. Scale bar $20 \mu \mathrm{m}$.

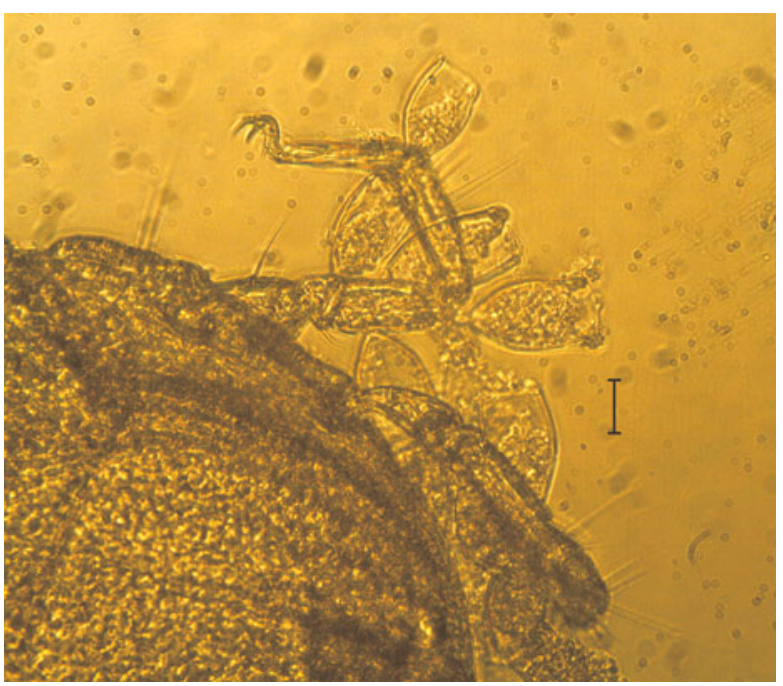

Fig. 4. Praethecacineta halacari attached to halacarid mite from Canada. Scale bar $20 \mu \mathrm{m}$.

\section{DISTRIBUTION}

Bulgaria and Ukraine (Black Sea); Norway, Kiel Bay of North Sea, Caspian Sea, Western Australia, Atlantic coast of Brazil, west coast of India (Schulz, 1933; Detcheva, 1992; Boshko \& Dovgal, 2004; Gelmboldt \& Dovgal, 2005; Pepato \& Tiago, 2005; Dovgal et al., 2008a). Taiwan, Tanzania and Canada (present report).

\section{HOST SPECIFICITY}

Praethecacineta halacari has been found attached to a variety of halacarid mites; viz. Copidognathus arabicus Chatterjee \& Chang, C. brifacius Bartsch, C. brachystomus Viets, C. magnipalpus (Police), C. meridianus Bartsch, C. tupinamborum Pepato \& Tiago, Copidognathus spp., Caspihalacarus hyrcanus Viets, and many unidentified species (Schulz, 1933; Detcheva, 1992; Boshko \& Dovgal, 2004; Gelmboldt \& Dovgal, 2005; Dovgal et al., 2008a). Copidognathus ungujaensis Chatterjee, De Troch \& Chang is also reported here for the first time as a host of P. halacari. Chatterjee et al. (2006) noted that many specimens of $C$. unguensis were infested by suctorians, which have been identified here as $P$. halacari. 
Table 1. Body dimensions of Praethecacineta halacari, measurements in $\mu \mathrm{m}$.

\begin{tabular}{lcccc}
\hline Characters & $\begin{array}{l}\text { Taiwan specimens } \\
\text { (present study) }\end{array}$ & $\begin{array}{l}\text { Tanzanian specimens } \\
\text { (present study) }\end{array}$ & $\begin{array}{l}\text { Canadian specimens } \\
\text { (present study) }\end{array}$ & $\begin{array}{l}\text { Indian specimens } \\
\text { after Dovgal } \text { et al., 20o8a }\end{array}$ \\
\hline Lorica length & $24-38$ & $30-35$ & $16-55$ & $31-38$ \\
Lorica width & $12-21$ & $19-21$ & $24-49$ & $18-21$ \\
Cell body length & $24-26$ & $22-29$ & $16-48$ & $35-55$ \\
Cell body width & $12-25$ & $12-18$ & $6-47$ & $3-10$ \\
Macronucleus diameter & $7-9$ & $5-10$ & $8-29$ & $3-26$ \\
Stalk length & $17-18$ & $7-16$ & $3-10$ & $50-110$ \\
Tentacle length & $3-6$ & $1-14$ & \\
\hline
\end{tabular}

\section{ACKNDWLEDGEMENTS}

Thanks are due to Dr M. Raes and Dr H. Gheerardyn, Ghent University, Belgium for collecting samples in Zanzibar. Thanks are also due to anonymous referees for their critical reading of the manuscript and useful comments.

\section{REFERENCES}

Boshko E.G. and Dovgal I.V. (2004) Sessile ciliates (Ciliophora). In Karadag. Hydrobiological observations (scientific works dedicated to 9oth anniversary of T.I. Vyazemsky Karadag Scientific Station and 25th anniversary of Karadag Natural Reserve of Ukrainian National Academy of Sciences). Book 2. Simferopol: Sonat, pp. 313-316. [In Russian.]

Chatterjee T., De Troch M. and Chang C.Y. (2006) Three halacarid mites of the genus Copidognathus (Acari, Halacaridae) from Zanzibar, Tanzania. Cahiers de Biologie Marine 47, 177-187.

Detcheva R. (1992) Catalogi faunae Bulgaricae. 1. Protozoa, Ciliophora. In Aedibus Academiae Scientiarum Bulgaricae. Sofia, 134 pp.

Dovgal I.V. (1996) Keys for identification of tentaculous infusoria (Ciliophora,Suctoria) of the Ukrainian fauna. Vestnik Zoologii Supplement N2, 1-42. [In Russian.]

Dovgal I.V. (2002) Evolution, phylogeny and classification of Suctorea Claparède et Lachmann, 1858. Protistology 2, 194-270.

Dovgal I., Chatterjee T. and Ingole B. (2008a) Suctorian ciliates (Ciliophora, Suctorea) as epibionts of halacarid mites (Acari: Halacaridae): an overview. Zootaxa 1810, 60-68.

Dovgal I., Chatterjee T., Ingole B. and Nanajkar M. (2008b) First report of Limnoricus ponticus Dovgal and Lozowskiy (Ciliophora, Suctorea) as epibionts on Pycnophyes (Kinorhyncha) from Indian Ocean with key to species of the genus Limnoricus. Cahiers de Biologie Marine $49,381-385$.

Gelmboldt M.V. and Dovgal I.V. (2005) The new finds of suctorian ciliates (Ciliophora, Suctorea) at the halacarid mites (Acari, Halacaridae) from the Ukrainian coast of the Black Sea. Vestnik Zoologii Supplement N19, 85-86. [In Russian.]

Ingole B., Singh R., Sautya S., Dovgal I. and Chatterjee T. (2009) Report of epibiont Thecacineta calix (Ciliophora, Suctorea) on deep sea Desmodora (Nematoda) from the Andaman Sea, Indian Ocean. JMBA 2 Biodiversity Records, Ref No. 6447, 1-4: Published online, January, 2009.

Jankowski A.V. (1981) New species, genera and families of tentacle infusoria (class Suctoria). Proceedings of the Zoological Institute of Russia $107,80-115$.

Jankowski A.V. (2007) Review of taxa Phylum Ciliophora Doflein, 1901. In Alimov A.F. (ed.) Protista: Handbook on zoology. Part 2. St Petersburg: Nauka, pp. 415-993.

Pepato A.R. and Tiago C.G. (2005) New species and new occurrences of Copidognathus (Acari, Halacaridae) from the northern littoral zone of São Paulo State (Brasil). Zootaxa 1083, 1-35.

Precht H. (1935) Epizoen der Kieler Bucht. Nova Acta Leopoldina Halle, NF 3, 405-474.

and

Schulz E. (1933) Beitrage zur Kenntnis marinen Suctorien. V. Zoologischer Anzeiger 103, 327-329.

\section{Correspondence should be addressed to:}

I. Dovgal

Schmalhausen Institute of Zoology

B. Khmelnitsky str, 15, 01601

Kiev, Ukraine

email: dovgal@izan.kiev.ua 